\title{
シューズの材料開発における技術動向
}

森貞 樹

\section{Technological Aspects of Shoe Material Development}

Sadaki MORI (Institute of Sport Science, ASICS Corporation,2-1,6-chome,Takatsukadai,Nishi-ku,Kobe 651-2271, Japan)

Materials used in shoes have been widely developed according to the application conditions. Especially shoe sole is an important part to produce high-performance and prevent injuries. On the other hand, not only the development of new sole material but also adhesive technology and molding process of each individual part are so important in the shoes designing process. A shoe sole is consisted of many kinds of materials, for example, high abrasion rubber, EVA sponge and resin, etc. These parts are adhered with solvent adhesion manually. Therefore sole fabrication processes take much time and the qualities, such as adhesive strength and sole durability, are unstable.

In this few years, adhesive and molding methods have been developed with considering environmental issue. In this paper, the current technological aspects, material development, adhesive, molding technology and environmental issue are presented.

Key Words : Shoe Material, Reactive-hot Melt Adhesive, Injection Molding Technology, Dismantlable Adhesion, Micro-wave, Recycle System

\section{1.は じめ に}

スポーツシューズは，その使用用途や条件，サーフェイ スの違いにより様々な材料が使用される。例えば体育館で 使用されるバスケットやバレーボールのソール（底材）に は主としてグリップ性と引張強度に優れた天然ゴムが使用 され，ランニングやマラソンシューズソールには耐摩耗性 に優れたブタジェンラバーが使用される。また，サッカー やラグビーなどのスパイクシューズには芝生上でのグリッ

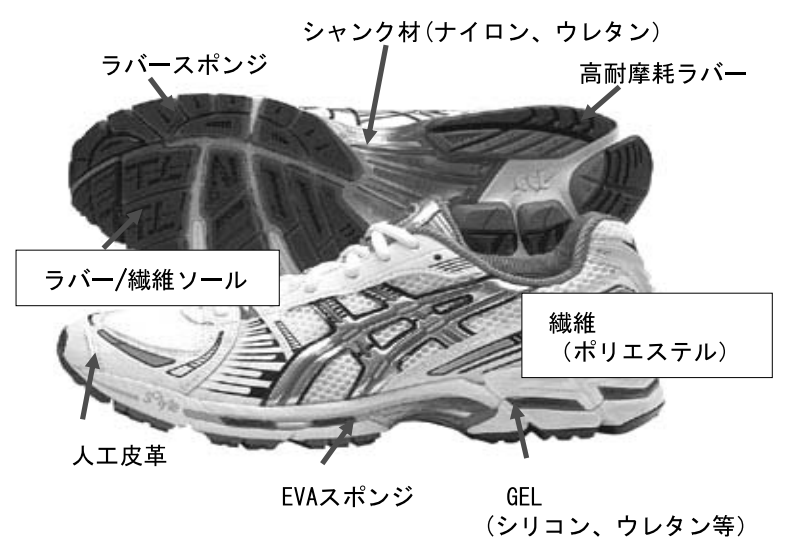

図 1 ランニングシューズに使用される材料
プ性や耐摩耗性を考慮した樹脂製 (ウレタン)ソールが一般 的となっている。一方, 眓1に示すように, 一足のシュー ズを見ても，ゴム，ゴムスポンジ， EVA（エチレン-酢酸 ビニル共重合体) スポンジ，プラスチック，合成繊維，人 工皮革，衝撃緩衝材などが使用されており，シューズを設 計する上で, 用途や要求性能に応じて様々な材料の知識が 必要となる.

さらに，異素材から構成されるシューズを成形する際に は，接着技術が重要となり，複雑な工程を要する。そのた め，製靴技術は未だ労働集約型の生産体制から脱却されて おらず，労働賃金の安価な国々へ生産工場が移転している のが現状である.

その一方, シューズの材料開発においては、将来に向け た様々な研究開発が取り組まれている。本書では，「材料

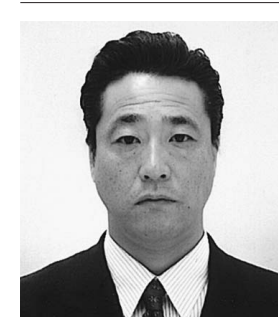

森＼cjkstart貞樹；侏アアシックススポーツ工学研究所 ( ₹ 651-2271 神戸市西区高塚台 6-2-1) 材料 開発チームマネージャー。1989年京都工芸繊 維大学繊維学部高分子学科卒業, 1989 年(秼) シックス入社, 現在に至る. 専門は材料力学, 高分子材料の成形加工．日本ゴム協会関西支 部幹事 
開発」，「接着技術」，「成形技術」，「環境配慮」をキーワー ドとし，最新の研究開発動向を紹介する。

2. シューズの材料開発について(超軽量ミッドソールの 開発)

一般にシューズのアッパー(足を包み込む部分) とアウタ ーソール (底材)の中間には衝撃を緩衝させるためのミッド ソールと呼ばれるスポンジ材が配される。従来ミッドソー ルの材質はEVAを架橋発泡させたスポンジが使用されて きた。その要因として，接着性，加工性，発泡成形性，物 理的特性が挙げられる。筆者は，従来当たり前とされてき た EVA製ミッドソールに着目し，「EVAを使用しなかっ たら，どのようなスポンジができるのだろう？」という疑 問から研究を開始した。様々な材料を用いた架橋発泡テス 卜を実施する中で，自動車のバンパーやスナック菓子の袋 に改質材として使用されている $\alpha$-オレフィンを使用する ことにより，EVAではなしえない軽量化の可能性を見出 した.さらに $\alpha$-オレフィンだけでは, 目標とする力学的 特性や比重などが達成できないことも明らかとなった。そ こで，高強度かつ発泡成形性に優れたスチレン系エラスト マーをブレンドし，それぞれの融点の差異から，二軸押出 機を利用したブレンド比率や混練方法などを検討した。ま た，そのコンパウンドを発泡させる時の架橋剤の添加量や 発泡剂の選択, 発泡条件など様々な点からも研究を行った。 その結果，従来にない新たなミッドソール素材を開発する ことができた。図 2 に開発した超軽量ミッドソールと従来 のミッドソールの写真を示す。超軽量ミッドソールは，約 半分の重量となっており，シューズの軽量化に大きな役割 を果たした。

さらに，本材料は単に軽量だけではなく，図 3 に示すよ うに使用する温度条件によりクッション性が一定であると いう特徵も併せ持つ。すなわち, 夏の炎天下で履こうが, 極寒の中で使用しようがシューズとしてのクッション性に 変化がないという優れた特徵をも併せ持つ。

本研究開発は，従来の概念にとらわれず，新たな発想を することにより，さらにシューズとしての機能性が向上で きた例と言える。

一方，シューズに用いられるスポンジは，架橋発泡成形 が一般的であり，金型内で架橋と発泡という化学反応を同 時に起こして成形される。このため, その成形条件は非常
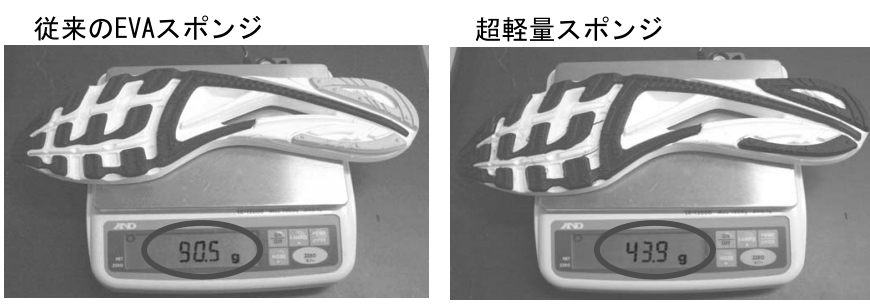

図 2 ミッドソールの重量比較

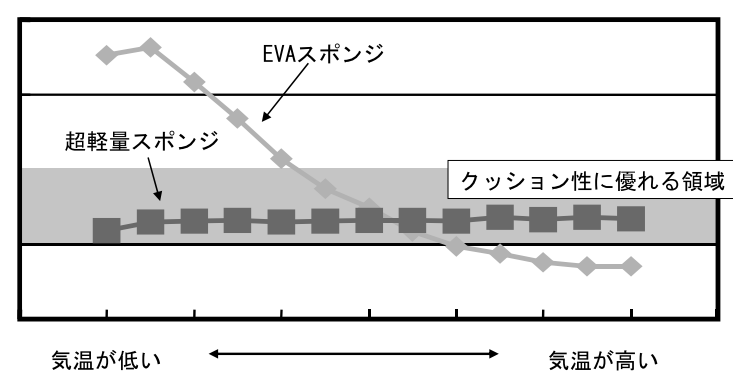

図 3 気温変化によるクッション性の変化

に複雑であり，これまで理論的に解明できない部分が非常 に多く残されており，経験と勘に頼っていた。本開発をき つかけに架橋発泡に関する基礎研究が取り組まれつつあ $ろ^{1,2)}$.

\section{3. 接着技術について}

シューズの製靴工程の中で，最も人手が必要とされ，時 間を要するのが接着工程である。この複雑な接着工程のた め，シューズの生産が労働賃金の安価な国々に移転してい る(図 4 ).シューズの接着工程が労働集約型から脱却でき ない主な理由として，以下の点が挙げられる。

・材料種が多い(処理方法が異なる)

・細かなパーツが多い(サイズ違いがある)

・時間がかかる

・有機溶剂を使用しているため労働者の健康面に良くない そこで，上記の課題を解決するため，短時間で，しかも

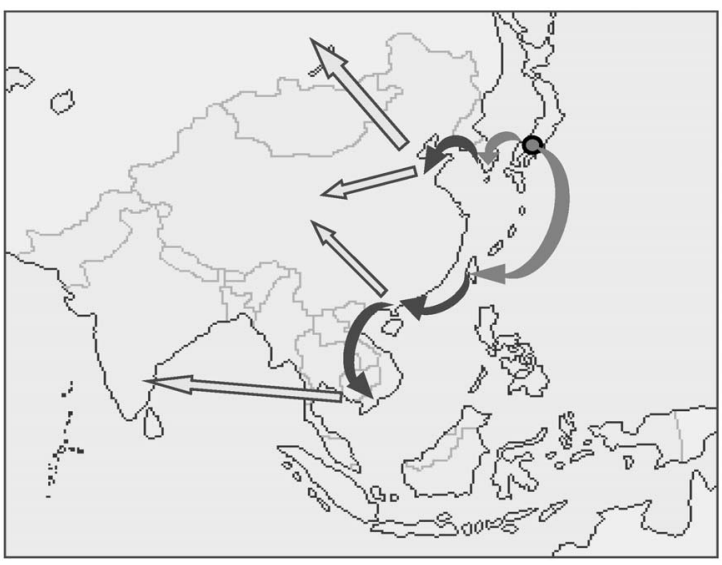

図 4 シューズ生産基地の推移

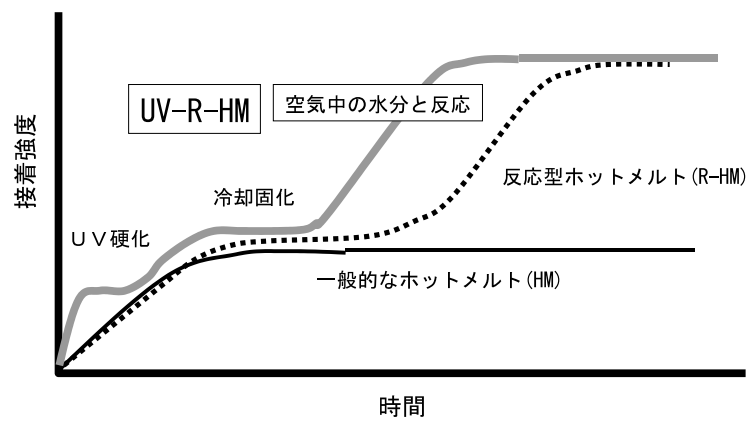

図 5 ホットメルト接着剤の時間と接着強度の関係 


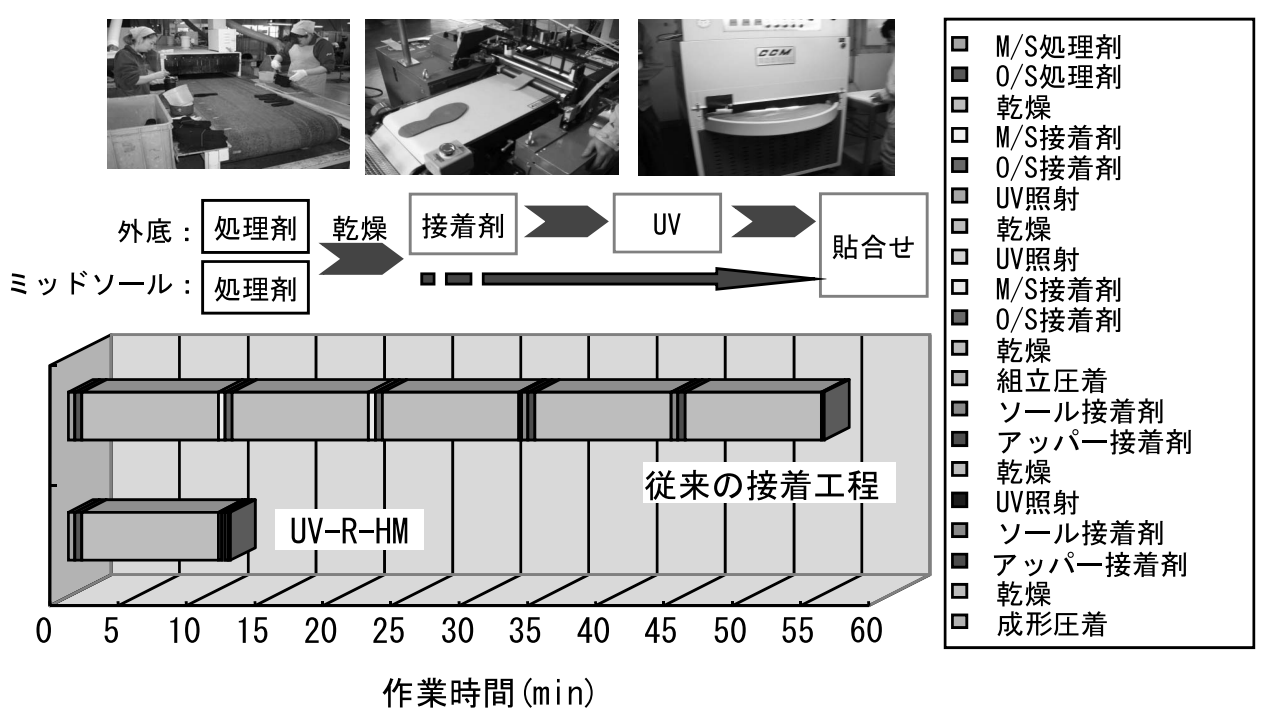

図 6 UV-R-HM と従来の接着工程の作業時間

半自動化が可能な「UV硬化型反応型ホットメルト接着剤 (以下，UV-R-HM)」のシューズ製靴工程への適用がなさ れた。UV-R-HMは，ホットメルト接着剤の無溶剂，短時 間接着という利点と空気中の水分との反応で高い接着力を 有する点を組み合わせた接着剤である。しかし，単なる反 応型タイプでは，接着工程中の各パーツの張り合わせが不 可能であり，初期にある程度の凝集力が必要であった。そ こで開発されたのが，紫外線 (UV) 照射により初期凝集力 を生み出すシューズ用の多段階硬化型ホットメルト接着剤 である。図 5 に概略を示す。

本接着剤を使用することにより，図 6 に示したように従 来の接着剂と比較して一部の塗布工程が機械化され，大幅 に接着時間が短縮され，しかも無溶剤となり環境面や労働 者の健康面にも配慮した接着工程が実現できた。本接着剤 の適用は，シューズ業界では初めての試みであり，国内の シューズ工場への導入が検討されている。

\section{4. 環境配慮について}

現在の社会情勢から，環境配慮は重要な問題である。一 般の家庭ゴミも分別廃棄が常識となっており，空き缶やぺ ットボトルなどもリサイクルが習慣化されている.しかし， シューズにおいては，使用後にそのままゴミ箱へ廃棄され ているのが現状である．上述したが，シューズは様々な材 料から構成され，しかも使用中に各パーツが容易に剥離し ないように強固に接着されている。しかし，廃棄時にこれ らのパーツごとに容易に分解することが可能であれば，分 別廃棄やリサイクルが促進されるであろう。そこで，使用 中は強固に接着されている各パーツを，短時間で容易に解 体可能な接着剤の開発が行われている.

解体性接着剂は, 接着剤中に澎張型発泡剂を添加し, 加 熱により容易に剥離できるものである。本技術 ${ }^{3)}$ は，文 献などによく紹介されているが，シューズの場合，構成さ れるパーツが耐熱性を有し得ないため，シューズ全体を加 熱することとなり，各パーツが熱により損傷を受け，リサ

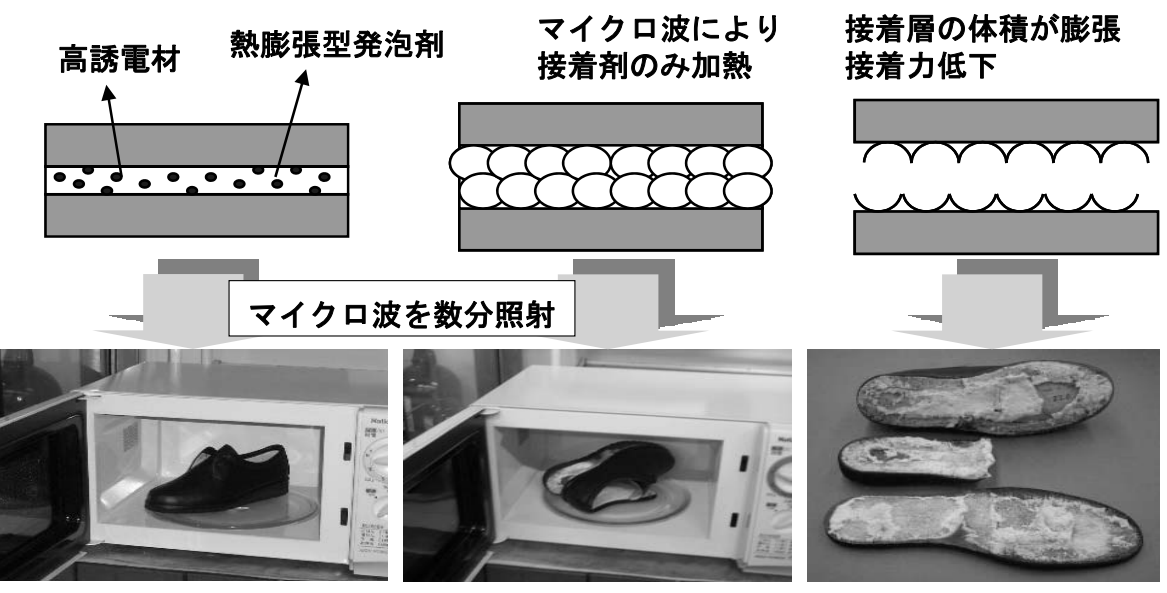

図 7 マイクロ波照射によるシューズの解体例 


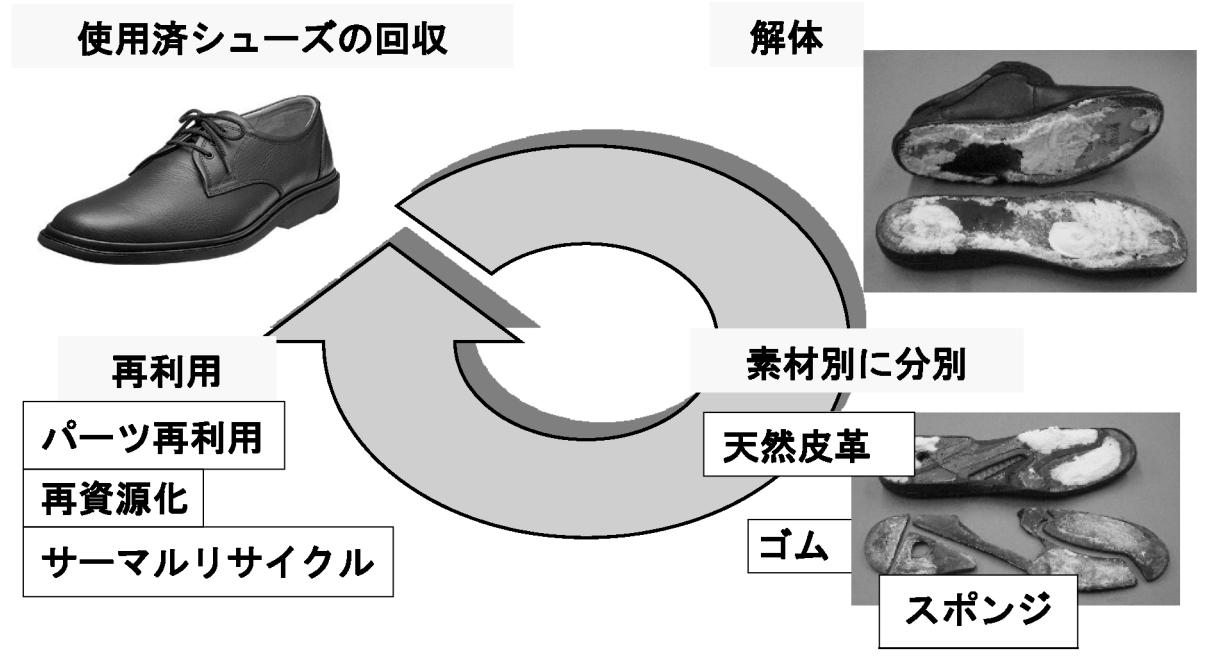

図 8 シューズリサイクルシステムの概要

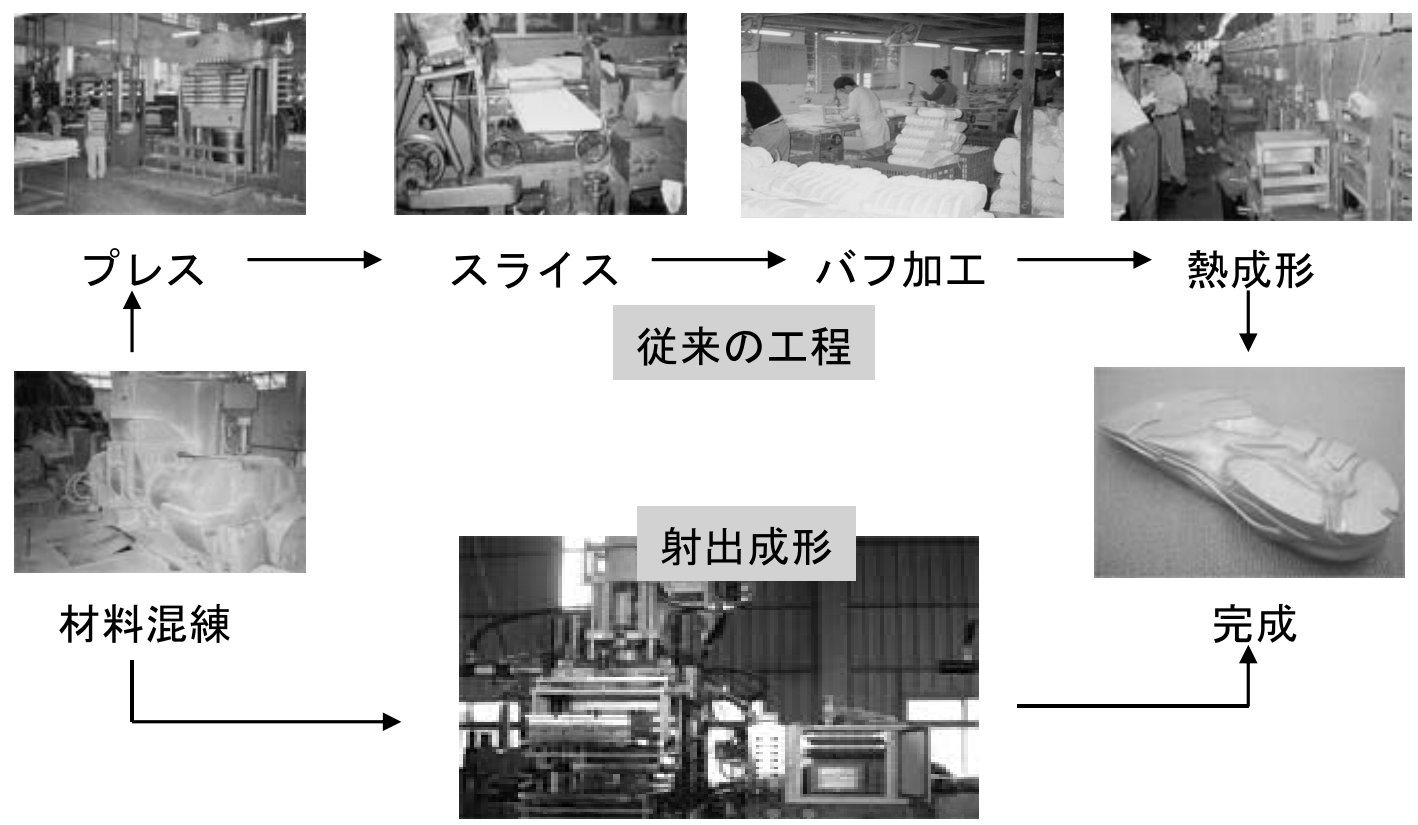

四 9 インジェクション製法によるミッドソールの成形工程

イクルが困難になる。さらに，夏場の乗用車のトランクを 想定した場合，シューズとしての機能を損なわないため， その温度下 $\left(\right.$ 約 $\left.70{ }^{\circ} \mathrm{C}\right)$ での発泡剂の膨張を避けなければな らないという課題があった。

そこで，解体したい部分(接着剂層)のみを部分的に加熱 し，発泡剂の膨張により容易に分解可能な接着技術を開発 した.

考案されたのは，マイクロ波(電子レンジ)を用いた部分 加熱による解体技術である。図 7 に模式図を示す。

膨張型発泡剤と高誘電剂を添加した接着剤に，マイクロ 波を 2 〜 分照射することにより，接着剤層のみが加熱さ れ, 接着剂に添加した膨張型発泡剂が発泡し, 急激に接着 力が低下する。

本手法を用いることにより，短時間で，しかも壊したい 部分のみを分解することが可能となり, さらに分解したパ
ーツは熱による損傷を受けていないため，容易に分別，リ サイクルが可能となる.

本接着剤の開発により，廃棄時に容易にシューズの分別 廃裹が可能となった. 現在は, 分別したパーツ毎に粉砕し, 新規材料に添加することにより新たな充てん剂として使用 する検討が実施されており，図 8 に示したような，環境に より配慮したシューズの循環型システムが計画されてい る.

\section{5. 省力化成形技術開発について}

5.1 インジェクション成形技術(ミッドソールスポンジ) 先にも述べたように，シューズの生産工程は労働集約型 に依存しており，労働賃金の安価な国々への移転を繰り返 している。このため，長納期化，技術の流出，ロットが大 きくなる等の問題がある。再び日本国内でのシューズの生 
産“Made in Japan”を目指した取り組みがなされている. その中で，接着工程とともにシューズの製靴工程において 人手を要するのが, ラバーやスポンジなどのパーツのプレ ス成形である。これらの成形工程を省力化するために，人 手をかけないで成形が可能なインジェクションによる成形 技術開発が有力とされている.

一般的なミッドソール (スポンジ成形)の従来の成形工程 とインジェクションを用いた場合の工程を図 9 に示す.

図 9 から明らかなように，ミッドソール一つのパーツを 見ても, 長い工程と多くの人手を要している. 本工程をイ ンジェクションにより，一回で複雑形状のミッドソールが 成形可能となれば，大幅な工程とコスト削減になり，さら に機械化であることから，品質のばらつきが少ない安定し た生産が期待できる。現状の，スポンジインジェクション 成形では，架橋と発泡という二つの化学反応により成形さ れるため，寸法や発泡安定性などの面で制御が困難となっ ている。一部のシューズにインジェクション成形を用いた スポンジが使用されるようになってきたが，今後更なる技 術向上により，軽量で機械特性に優れたインジェクション 製法によるスポンジの開発が急務となる。

\section{2 インジェクション成形技術(アウターソール用ラ バースポンジ)}

ミッドソールと同様にアウターソールに使用されるラバ ースポンジに関しても，インジェクションによる成形技術 が開発されている。

アウターソールは，ミッドソールスポンジと異なり，直 接地面と接することから, 耐摩耗性やグリップ性が要求さ れ，配合中のゴム成分の添加比率が高くなる。このため， 成形後の収縮や硬度変化が大きくなる，さらに，細かな意 匠形状が求められるために，架橋速度の調整や高粘度の材 料の成形条件など，課題は多く残る。現状では比較的単純 な形状の単色ソールに限定された使用となっている.今後,
さらにインジェクションに適した材料設計や高粘度材料の 射出シミュレーション技術が進化することにより，より複 雑で, 生産効率に優れ, 多色使いのソール開発が可能とな ると考えられる。

\section{6.お わりに}

“足”は第二の心藏と呼ばれるように，人間の体にとっ て重要な部分である。その重要な部分である足に装着する シューズにおける材料設計には, 着用者をけがから保護し, スポーツにおいては選手の能力を最大限に発揮させ，さら に全ての使用環境において快適な生活を提供することが求 められる。他業種の材料開発と異なるのは，直接人が身に 装着するため，材料の評価を主観的評価に委ねざるを得な いという点も重要な要素となる. そのため，様々な用途に 適した材料開発がなされているが，今後はこれら感覚を定 量化し，それを指標とした材料設計が必要となる。さらに， 高機能, 高品質を維持し, 安定してユーザーに供給するた め，単なる材料開発だけでなく，それに付随する成形技術 や接着技術の益々の進歩が急務であると考えられる。

\section{References}

1) Tateishi, J.; Mori, S.; Imazato, K.; Nagatani, A.; Washiya,H.: Nippon Gomu Kyokai Elastomer Touronkai Youshisyu, 19, 118 (2008)

2 ) Tateishi, J.; Mori, S.; Imazato, K.; Nagatani, A.; Washiya, H.: Plastics Seikei Kakou Gakkai Nenji Taikai Text, 19, 217 (2008)

3 ) Sato, C.: Nippon Gomu Kyoukaishi, 81, 18 (2008)

\section{日本語表記参考文献}

1 ) 立石純一郎, 森貞樹, 今里克博, 長谷朝博, 熟家洋彦: 日本ゴ ム協会エラストマー討論会講演要旨集，19，118（2007）

2 ) 立石純一郎, 森貞樹, 今里克博, 長谷朝博, 鷲家洋彦: プラス チック成形加工学会年次大会テキスト，19，217 (2008)

3 ）佐藤千明：日本ゴム協会誌， 81，18 (2008) 